\title{
Acute interstitial nephritis associated with ingestion of Achyranthes japonica extract: a case report
}

\author{
Ha Nee Jang', Sehyun Jung ${ }^{1}$, Seunghye Lee ${ }^{1}$, Se-Ho Chang ${ }^{1,2,3}$, Tae Won Lee ${ }^{4}$, Eunjin Bae ${ }^{2,3,4}$ and \\ Dong Jun Park ${ }^{2,3,4^{*}}$ (D)
}

\begin{abstract}
Background: The Japanese chaff flower, Achyranthes japonica, is used as complementary medicine to control degenerative arthritis. Although commonly used in South Korea, there has been no report of side effects. We report the first case of acute interstitial nephritis (AIN) that occurred in a woman who ingested A. japonica extract for 4 months.

Case presentation: A 56-year-old Korean woman was admitted for deterioration of renal function. She had general weakness and nausea for 1 month. Her initial blood urea nitrogen and serum creatinine levels were $26.3 \mathrm{mg} / \mathrm{dL}$ and $3.2 \mathrm{mg} / \mathrm{dL}$, respectively. She acknowledged ingesting A. japonica extract for the past 4 months. Renal histology demonstrated AIN represented by immune cell infiltration into the interstitium, tubulitis, and tubular atrophy, but the glomeruli were intact. A. japonica was discontinued immediately and conservative management was started. Renal function was nearly restored to the baseline level without medication after 13 months.

Conclusion: This is a rare case report of AIN associated with a pure A. japonica extract. In the case of unknown etiology of AIN, physicians should ask about the use of herbal medicines, nutraceuticals, and traditional folk medicines including A. japonica.
\end{abstract}

Keywords: Achyranthes japonica, Nephritis, Drugs, Nutraceuticals, Side effects

\section{Background}

Acute interstitial nephritis (AIN) occurs when acute kidney injury (AKI) is accompanied by histological findings of interstitial inflammation, edema, and tubulitis. AIN is a common cause of AKI $[1,2]$. Drug-induced AIN is known to account for $60-70 \%$ of cases [1], but the incidence of AIN caused by herbs or folk medicines is unknown and often ignored. Single or concurrent use of herbs with therapeutic drugs could increase the potential

\footnotetext{
* Correspondence: drpdj@naver.com

${ }^{2}$ Department of Internal Medicine, College of Medicine, Gyeongsang National University, Jinju, South Korea

${ }^{3}$ Institute of Health Science, Gyeongsang National University, Jinju, South Korea

Full list of author information is available at the end of the article
}

for side effects. Traditional herbal medicines have been widely used in South Korea for a long time. The Japanese chaff flower, Achyranthes japonica, has been used as complementary medicine for edema and arthritis and to delay a woman's menstruation without clinical evidence. Recent studies have reported the antiinflammatory, pain relief, and antibacterial effects of $A$. japonica as well as its ability to improve osteoporosis conditions in ovariectomized rats [3-6]. However, there has been no report on side effects. Therefore, we report a case of AIN after ingesting $A$. japonica. This case report suggests that ingesting a complementary medicine could be a cause of AKI leading to chronic kidney disease (CKD) if management is delayed.

(c) The Author(s). 2021 Open Access This article is licensed under a Creative Commons Attribution 4.0 International License, which permits use, sharing, adaptation, distribution and reproduction in any medium or format, as long as you give appropriate credit to the original author(s) and the source, provide a link to the Creative Commons licence, and indicate if changes were made. The images or other third party material in this article are included in the article's Creative Commons licence, unless indicated otherwise in a credit line to the material. If material is not included in the article's Creative Commons licence and your intended use is not permitted by statutory regulation or exceeds the permitted use, you will need to obtain permission directly from the copyright holder. To view a copy of this licence, visit http://creativecommons.org/licenses/by/4.0/ The Creative Commons Public Domain Dedication waiver (http://creativecommons.org/publicdomain/zero/1.0/) applies to the data made available in this article, unless otherwise stated in a credit line to the data. 


\section{Case presentation}

A 56-year-old Korean woman was admitted for deterioration of renal function. She had suffered from general weakness and nausea for the past month and visited a local clinic. She was recommended to visit the tertiary hospital because of poor renal function. She was a farmer, but she strongly denied any recent exposure to pesticides. She had intermittently taken medicines for arthralgia in both knees. She had been diagnosed with hypertension 3 years previously and was taking $5 \mathrm{mg}$ lercanidipine without change. She had a routine check-up 1 year ago and did not show any abnormalities of renal function at that time. She also denied various infections and other systemic or auto-immune diseases that cause acute TIN by a thorough history taking. However, she complained of a $5-\mathrm{kg}$ weight loss in the last 3 months. She did not complain of fever, oliguria, skin rash, or a urine color change at admission. She had not taken NSAIDs, toxins, or Chinese herbal medicines, but had ingested the extract of $A$. japonica for control of knee pain beginning 4 months ago.

Her initial vital signs were as follow: blood pressure of $140 / 80 \mathrm{mmHg}$, heart rate of 68 beats/min, respiratory rate of 20 breaths/min, and body temperature of $36.1{ }^{\circ} \mathrm{C}$. No remarkable findings were observed in the physical examinations. Her complete blood count $(\mathrm{CBC})$, biochemical findings, and arterial blood gas analysis was shown Table 1. Briefly, her blood urea nitrogen and creatinine were elevated whereas potassium level decreased. There was no eosinophilia on her CBC. A arterial blood gas analysis was compatible with metabolic acidosis and anion gap was normal. C3 and C4 levels were $102 \mathrm{mg} / \mathrm{dL}$ (normal, $90-180 \mathrm{mg} / \mathrm{dL}$ ) and $26.9 \mathrm{mg} / \mathrm{dL}$ (normal, 10$40 \mathrm{mg} / \mathrm{dL}$ ), respectively. Immunoglobulin G (IgG), IgA, and IgM levels were $2530 \mathrm{mg} / \mathrm{dL}$ (normal, 700-1600 mg/ $\mathrm{dL}$ ), $689 \mathrm{mg} / \mathrm{dL}$ (normal, 70-400 mg/dL), and $171 \mathrm{mg} / \mathrm{dL}$ (normal, 40-230 mg/dL. Anti-nuclear antibody, antineutrophilic cytoplasmic antibody, and anti-glomerular basement membrane antibody were all negative. A urinalysis revealed $1+$ protein, 2+ blood, and 3+ glucose by dipstick. Microscopy revealed 10-29 red blood cells/high power field (HPF) and many WBCs/HPF. No bacteria grew on a urine culture. No eosinophils existed on Hansel staining of the urine.

Protein $(1406 \mathrm{mg}$ ) was detected in the 24-h urine sample. There was no evidence of monoclonal gammopathy in the serum or urine protein on the immunoelectrophoresis assay.

Kidney size was normal on ultrasonography (USG) $(10.5 \mathrm{~cm}$ right and $11.0 \mathrm{~cm}$ left) with normal echogenicity, and a Doppler study was unremarkable. USG-guided renal biopsy revealed moderate and diffuse interstitial lymphocyte infiltration with mild tubular atrophy, and lymphocytic tubulitis was also
Table 1 Serum laboratory findings

\begin{tabular}{|c|c|}
\hline \multicolumn{2}{|l|}{ Complete blood count (CBC) } \\
\hline WBC $\left(4.0-10.0 \times 10^{9} / \mathrm{L}\right)$ & $4.94 \times 10^{9} / \mathrm{L}$ \\
\hline Neutrophil (50-75\%) & $49.2 \%$ \\
\hline Lymphocyte (20-44\%) & $37.7 \%$ \\
\hline Monocyte (2-9\%) & $6.5 \%$ \\
\hline Eosinophil (1-5\%) & $3.8 \%$ \\
\hline Hemoglobin (12-16 g/dL) & ${ }^{\mathrm{a}} 9.1 \mathrm{~g} / \mathrm{dL}$ \\
\hline Hematocrit (36-48\%) & ${ }^{\mathrm{a}} 26 \%$ \\
\hline Platelet $\left(130-400 \times 10^{9} / \mathrm{L}\right)$ & $142 \times 10^{9} / \mathrm{L}$ \\
\hline \multicolumn{2}{|l|}{ Biochemical findings } \\
\hline BUN (8.0-20.0 mg/dL) & ${ }^{\mathrm{a}} 26.3 \mathrm{mg} / \mathrm{dL}$ \\
\hline Creatinine $(0.51-0.95 \mathrm{mg} / \mathrm{dL})$ & ${ }^{\mathrm{a}} 3.2 \mathrm{mg} / \mathrm{dL}$ \\
\hline Sodium (135-145 mmol/L) & $137 \mathrm{mmol} / \mathrm{L}$ \\
\hline Potassium (3.3-5.1 mmol/L) & ${ }^{\mathrm{a}} 3.0 \mathrm{mmol} / \mathrm{L}$ \\
\hline Chloride (98-110 mmol/L) & $112 \mathrm{mmol} / \mathrm{L}$ \\
\hline Total $\mathrm{CO}_{2}(21-31 \mathrm{mmol} / \mathrm{L})$ & ${ }^{\mathrm{a}} 17 \mathrm{mmol} / \mathrm{L}$ \\
\hline Glucose (70-110 mg/dL) & $190 \mathrm{mg} / \mathrm{dL}$ \\
\hline Protein $(6.6-8.7 \mathrm{~g} / \mathrm{dL})$ & $8.1 \mathrm{~g} / \mathrm{dL}$ \\
\hline Albumin $(3.5-5.2 \mathrm{~g} / \mathrm{dL})$ & $3.9 \mathrm{~g} / \mathrm{dL}$ \\
\hline Calcium (8.6-10.2 mg/dL) & $9.5 \mathrm{mg} / \mathrm{dL}$ \\
\hline Phosphorus (2.7-4.5 mg/dL) & $2.4 \mathrm{mg} / \mathrm{dL}$ \\
\hline $\operatorname{HbA1c}(4.2-5.9 \%)$ & $5.0 \%$ \\
\hline \multicolumn{2}{|l|}{ Arterial blood gas analysis } \\
\hline $\mathrm{pH}(7.35-7.45)$ & a 7.29 \\
\hline Bicarbonate (24-30 mmol/L) & ${ }^{\mathrm{a}} 17 \mathrm{mmol} / \mathrm{L}$ \\
\hline pCO2 (32-46 mmHg) & ${ }^{\mathrm{a}} 35 \mathrm{mmHg}$ \\
\hline
\end{tabular}

WBC White blood cell, BUN Blood urea nitrogen. a abnormal value

frequently found on higher magnification (Fig. 1a and b). The glomeruli were normally sized and cellularity and capillary walls were not thickened. The blood vessels were unremarkable. Imminofluorescence microscopy was negative. As she had not taken any medicines except for anti-hypertensive drugs for the past 3 years without changes, A. japonica was considered the causative agent of the tubulointerstitial nephritis (TIN) and was immediately withdrawn. Conservative management, including appropriate blood pressure control, a low salt diet, and oral potassium and bicarbonate replacement was started. Her initial symptoms and signs improved and blood pressure was well controlled without further medication.

She was discharged on day 10 after admission and followed up in the outpatient department. The abnormal urinalysis findings resolved completely, and oral potassium and bicarbonate administration was withdrawn 13months after discharge. Serum creatinine was $1.05 \mathrm{mg} /$ $\mathrm{dL}$ and the estimated glomerular filtration rate was 57 $\mathrm{ml} / \mathrm{min} / 1.73 \mathrm{~m}^{2}$ 24-months after discharge (Fig. 2). She 
A

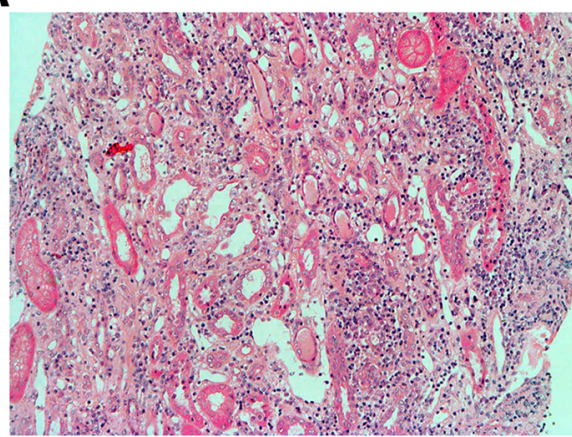

B

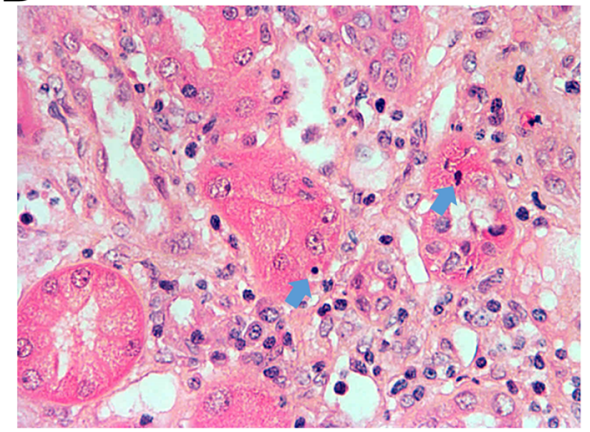

Fig. 1 Histologic findings of renal biopsy. There is moderate and diffuse lymphocytic infiltration into interstitium with mild tubular atrophy (a) $(x$ 100, H\&E staining). Lymphocytic tubulitis (bold arrow) are frequently found on higher magnification (b) $(\times 400$, H\&E staining)

is currently being followed up in our outpatient department with the maintenance of renal function.

\section{Discussion and conclusions}

We described a case of AIN that occurred after ingesting A. japonica for 4 months. As far as we know, this is the first report in the English literature. There are numerous cases of unexplained decreased renal function in a clinical setting. This report is significant in that careful and thorough history taking of medications, including Chinese herbal medicines, nutraceuticals, and traditional folk medicines are essential to diagnose and treat AIN.

AIN is usually confirmed when AKI is accompanied by histological findings of interstitial inflammation, edema, and tubulitis. Many etiologies of AIN have been recognized, including drugs, various infections, autoimmune or systemic diseases, and idiopathic diseases [1, 2]. A report of pooled data from three large studies revealed that drugs were the most common etiology of AIN, underlying 91 of 128 cases (71.1\%) [7]. AIN induced by drugs has been observed in $6.5-27 \%$ of patients when a renal biopsy was performed due to unexplained AKI [8-10]. AIN has been reported after ingesting herbal and folk medicines [11-13]. A. japonica has been ingested in South Korea for a long time to control arthralgia. However, there have been no reports of adverse effects.

Although acute TIN has a good prognosis when diagnosed early, the causative agents are withdrawn and, where necessary, early steroid therapy is started; undetected subclinical acute TIN can progress to renal fibrosis and eventually cause irreversible CKD [2]. Schwarz et al. revealed that drug-related AIN causes permanent renal insufficiency in $36 \%$ of cases with a

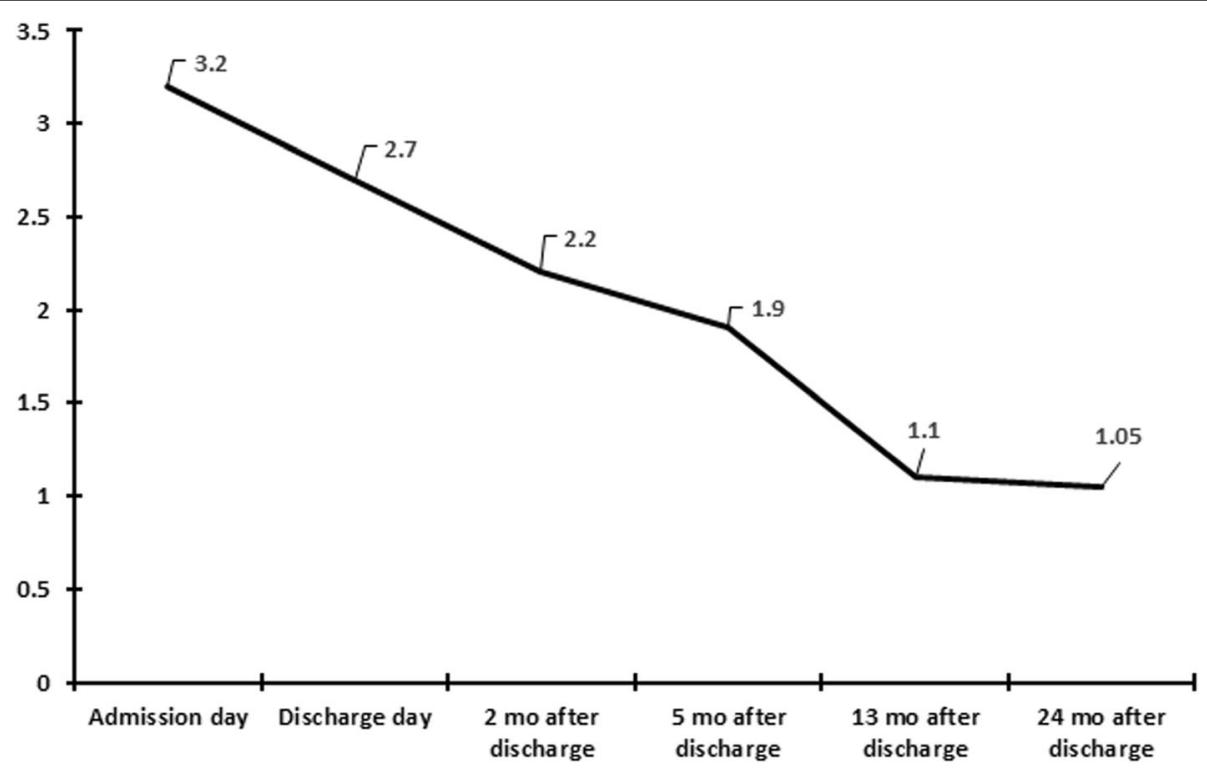

Fig. 2 Serial changes of serum creatinine during admission and after discharge 
maximum of $56 \%$ in NSAID-induced cases and taking the suspected drug for more than 1 month before the diagnosis causes permanent renal insufficiency in $88 \%$ of cases. Less oliguria and anuria as acute symptoms and prolonged intake of the suspected drug are related to a more chronic course of interstitial nephritis [14]. Other studies also showed that acute TIN-related damage is a potential promoter of CKD and the duration of treatment and the cumulative dose appear to increase the risk of kidney damage $[15,16]$. Our patient had ingested A. japonica for 4 months and the renal histology revealed moderate interstitial cell infiltration and mild tubular atrophy, resulting in long-term restoration of renal function and some irreversibility. Two formal methods are available for calculating the probability of causation: the Naranjo probability scale [17] and the World Health Organization-Uppsala Monitoring Center (WHO-UMC) causality categories [18]. The patient's Naranjo probability scale score was 6 (probable causal relationship) and her WHO-UMC causality category was "probable".

AIN is also characterized by tubulitis, which is the extension of interstitial inflammation over the tubular basement membranes. Patients with AIN can present with tubular dysfunction, which includes salt-wasting nephropathy, abnormal renal acidification, urinary concentration defects, potassium secretory defects related to distal nephron injury, or defective proximal tubular reabsorption leading to features of Fanconi's syndrome presented as glycosuria, phosphaturia, aminoaciduria, hypokalemia, and type II renal tubular acidosis from bicarbonaturia [19]. Our patient also presented with both tubulitis and laboratory features of tubular dysfunction, such as hypokalemia, glycosuria, non-nephrotic proteinuria, and normal anion gap metabolic acidosis. The tubular dysfunction improved 13 months after withdrawing the $A$. japonica and restoration of renal function.

The pathogenesis of drug-induced AIN generally involves allergic reaction that is prompted by exposure to certain drug. As a result, T-cell mediated hypersensitivity reactions and cytotoxic T-cell injuries are involved in pathogenesis of drug-induced AIN $[1,19,20]$. The precise disease mechanism to give rise to AIN by Achyranthes japonica is not clear based on our one reported case, but antigen-driven immunopathology by exposure to this drug seems to be NSAID-associated AIN in that there was no clinical symptoms and signs such as fever, rash, arthralgia, and eosinophilia, it took about 6-18 months to develop AIN from the exposure than other drugs, and eosinophil rarely infiltrated into renal interstitium [21]. These clinical and pathological characteristics might be derived from anti-inflammatory properties of this agent.
We firstly report the case of AIN associated with a pure A. japonica extract which is widely taken as complementary medicine in South Korea. AIN should be considered in the differential diagnosis of all cases of AKI. Physicians should not only ask about prescribed and an over-the-counter drugs that cause AIN, but also about herbal medicines, nutraceuticals, and traditional folk medicines including $A$. japonica.

\section{Abbreviations \\ AIN: Acute interstitial nephritis; AKI: Acute kidney injury; CKD: Chronic kidney disease; HPF: High-power field; IgG: Immunoglobulin G; NSAIDs: Non- steroidal anti-inflammatory drugs; TIN: Tubulointerstitial nephritis; USG: Ultrasonography; WBC: White blood cell; WHO-UMC: World Health Organization-Uppsala Monitoring centre}

\section{Acknowledgements}

Not applicable.

\section{Authors' contributions}

DJP designed the study. SJ collected and interpreted the data. SJ and SL initially drafted the manuscript. HNJ, TWL, and EB helped to prepare, review, and revise the manuscript. DJP and SC further supervised the work. All authors contributed to and approved the final manuscript.

\section{Funding}

None.

\section{Availability of data and materials}

The data supporting the conclusions of this article is included within the article.

\section{Declarations}

Ethics approval and consent to participate

We respected patient's privacy and protected her identity. The study protocol was approved by the Institutional Review Board of Gyeongsang National University Changwon Hospital (IRB no. 2020-05-001). Informed consent was obtained from the patient.

\section{Consent for publication}

The patient provided written informed consent for publication.

\section{Competing interests}

The authors declare that they have not any financial and non-financial competing interests.

\section{Author details}

'Department of Internal Medicine, Gyeongsang National University Hospital, Jinju, South Korea. ${ }^{2}$ Department of Internal Medicine, College of Medicine, Gyeongsang National University, Jinju, South Korea. ${ }^{3}$ Institute of Health Science, Gyeongsang National University, Jinju, South Korea. ${ }^{4}$ Department of Internal Medicine, Gyeongsang National University Changwon Hospital, 11

Samjungja-ro Sungsan-gu, Changwon 51472, South Korea.

Received: 12 January 2021 Accepted: 28 March 2021

Published online: 07 April 2021

\section{References}

1. Perazella MA, Markowitz GS. Drug-induced acute interstitial nephritis. Nat Rev Nephrol. 2010;6(8):461-70. https://doi.org/10.1038/nrneph.2010.71.

2. Fernández Juárez GM, Villacorta Pérez J, Caravaca Fontán F, Cases Corona C, Sánchez Alamo B, Tato Ribera AM. New challenges in tubulointerstitial nephritis induced by drugs. Nefrologia. 2019;39(4):339-42. https://doi.org/1 0.1016/j.nefro.2019.02.003.

3. Lee SG, Lee EJ, Park WD, Kim JB, Kim EO, Choi SW. Anti-inflammatory and anti-osteoarthritis effects of fermented Achyranthes japonica Nakai. J Ethnopharmacol. 2012;142(3):634-41. https://doi.org/10.1016/j.jep.2012. 05.020. 
4. Bang SY, Kim JH, Kim HY, Lee YJ, Park SY, et al. Achyranthes japonica exhibits anti-inflammatory effect via NF-kB suppression and $\mathrm{HO}-1$ induction in macrophages. J Ethnopharmacol. 2012;144(1):109-17. https://doi.org/10.1 016/j.jep.2012.08.037.

5. Park HJ, Lee JS, Hong MS, Kim CJ, Kim JW, et al. The anti-nociceptive and anti-inflammatory effect of Achyranthes japonica Nakai. Korean J Oriental Med. 2004:25:8-14.

6. Kim JS, Lee SW, Kim SK, Na SW, Kim YO. Osteoprotective effect of extract from Achyranthes japonica in ovariectomized rats. J Exerc Rehabil. 2014; 10(6):372-7. https://doi.org/10.12965/jer.140169.

7. Baker RJ, Pusey CD. The changing profile of acute tubulointerstitial nephritis. Nephrol Dial Transplant. 2004;19(1):8-11. https://doi.org/10.1093/ndt/gfg464.

8. Davison AM, Jones $\mathrm{CH}$. Acute interstitial nephritis in the elderly: a report from the UK MDC glomerulonephritis register and a review of the literature. Nephrol Dial Transplant. 1998;13(90007):12-6. https://doi.org/10.1093/ ndt/13.suppl_7.12.

9. Clarkson MR, Giblin L, O'Connell FP, O'Kelly P, Walshe JJ, et al. Acute interstitial nephritis: clinical features and response to corticosteroid therapy. Nephrol Dial Transplant. 2004;19(11):2778-83. https://doi.org/10.1093/ndt/ gfh485.

10. Farrington K, Levison DA, Greenwood RN, Cattell WR, Baker LR. Renal biopsy in patients with unexplained renal impairment and normal kidney size. Q J Med. 1989;70(263):221-33.

11. Lee WY, Park BC, Kim HS, Joung OK, Yoon SI, et al. A case of acute interstitial nephropathy and toxic hepatitis after short-term herbal medication. Korean J Med. 2007:73:103-6.

12. Jeon JM, Park YK, Jeon MY. Corni Fructus-induced acute interstitial nephritis. Korean J Med. 2013;85(5):526-9. https://doi.org/10.3904/kjm.2013.85.5.526.

13. Beniwal P, Gaur N, Singh SK, Raveendran N, Malhotra V. How harmful can herbal remedies be? A case of severe acute tubulointerstitial nephritis. Indian J Nephrol. 2017;27(6):459-61. https://doi.org/10.4103/ijn.IJN_313_16.

14. Schwarz A, Krause PH, Kunzendorf U, Keller F, Distler A. The outcome of acute interstitial nephritis: risk factors for the transition from acute to chronic interstitial nephritis. Clin Nephrol. 2000;54(3):179-90.

15. Lazarus B, Chen Y, Wilson FP, Sang Y, Chang AR, Coresh J, et al. Proton pump inhibitor use and the risk of chronic kidney disease. JAMA Intern Med. 2016;176(2):238-46. https://doi.org/10.1001/jamainternmed.2015.7193.

16. Xie Y, Bowe B, Li T, Xian H, Balasubramanian S, Al-Aly Z. Proton pump inhibitors and risk of incident CKD and progression to ESRD. J Am Soc Nephrol. 2016;27(10):3153-63. https://doi.org/10.1681/ASN.2015121377.

17. Naranjo CA, Busto U, Sellers EM, Sandor P, Ruiz I, Roberts EA, et al. A method for estimating the probability of adverse drug reactions. Clin Pharmocol Ther. 1981;30(2):239-45. https://doi.org/10.1038/clpt.1981.154.

18. Edwards IR, Aronson JK. Adverse drug reactions: definitions, diagnosis, and management. Lancet. 2000;356(9237):1255-19. https://doi.org/10.1016/S014 0-6736(00)02799-9.

19. Rossert J. Drug-induced acute interstitial nephritis. Kidney Int. 2001;60(2): 804-17. https://doi.org/10.1046/j.1523-1755.2001.060002804.x.

20. Michel DM, Kelly CJ. Acute interstitial nephritis. J Am Soc Nephrol. 1998;9(3): 506-15.

21. Pirani CL, Valeri A, D'Agat V, Appel GB. Renal toxicity of nonsteroidal antiinflammatory drugs. Contrib Nephrol. 1987;55:159-75. https://doi.org/10.11 59/000413416.

\section{Publisher's Note}

Springer Nature remains neutral with regard to jurisdictional claims in published maps and institutional affiliations.

Ready to submit your research? Choose BMC and benefit from:

- fast, convenient online submission

- thorough peer review by experienced researchers in your field

- rapid publication on acceptance

- support for research data, including large and complex data types

- gold Open Access which fosters wider collaboration and increased citations

- maximum visibility for your research: over $100 \mathrm{M}$ website views per year

At BMC, research is always in progress.

Learn more biomedcentral.com/submissions 